\title{
The blue water footprint of electricity from hydropower
}

\author{
M. M. Mekonnen and A. Y. Hoekstra \\ Department of Water Engineering and Management, Univ. of Twente, P.O. Box 217, 7500 AE Enschede, The Netherlands
}

Correspondence to: M. M. Mekonnen (m.m.mekonnen@ctw.utwente.nl)

Received: 31 August 2011 - Published in Hydrol. Earth Syst. Sci. Discuss.: 8 September 2011

Revised: 13 January 2012 - Accepted: 16 January 2012 - Published: 20 January 2012

\begin{abstract}
Hydropower accounts for about $16 \%$ of the world's electricity supply. It has been debated whether hydroelectric generation is merely an in-stream water user or whether it also consumes water. In this paper we provide scientific support for the argument that hydroelectric generation is in most cases a significant water consumer. The study assesses the blue water footprint of hydroelectricity - the water evaporated from manmade reservoirs to produce electric energy - for 35 selected sites. The aggregated blue water footprint of the selected hydropower plants is $90 \mathrm{Gm}^{3} \mathrm{yr}^{-1}$, which is equivalent to $10 \%$ of the blue water footprint of global crop production in the year 2000. The total blue water footprint of hydroelectric generation in the world must be considerably larger if one considers the fact that this study covers only $8 \%$ of the global installed hydroelectric capacity. Hydroelectric generation is thus a significant water consumer. The average water footprint of the selected hydropower plants is $68 \mathrm{~m}^{3} \mathrm{GJ}^{-1}$. Great differences in water footprint among hydropower plants exist, due to differences in climate in the places where the plants are situated, but more importantly as a result of large differences in the area flooded per unit of installed hydroelectric capacity. We recommend that water footprint assessment is added as a component in evaluations of newly proposed hydropower plants as well as in the evaluation of existing hydroelectric dams, so that the consequences of the water footprint of hydroelectric generation on downstream environmental flows and other water users can be evaluated.
\end{abstract}

\section{Introduction}

The need to supply a growing population with sufficient fresh water in the context of increasing water scarcity and declining water quality has brought sustainable water resources management to the forefront of the global development agenda. For centuries, dams have played a key role in human development, bringing about significant social and economic improvements, but also having significant impacts on local communities and ecosystems. About $30-40 \%$ of irrigated land worldwide relies on water stored behind dams (World Commission on Dams, 2000) and hydropower accounted for $16 \%$ of world electricity in 2008 (IEA, 2010).

Large hydropower dams have both positive and negative effects (Sternberg, 2008, 2010). Dams have been built to regulate river flows, store water to guarantee adequate supply of water in dry periods, control floods, irrigate agricultural lands, provide for navigation and to generate electricity. Negative impacts associated with the building of large dams include displacement of people, loss of land and alteration of river flows and water quality affecting downstream people and ecosystems (Gleick, 1993; Rosenberg et al., 1995; Poff et al., 1997; Scudder, 1997; Lerer and Scudder, 1999; Tilt et al., 2009). Worldwide, many countries are likely to continue depending on hydroelectric dams as their source of electricity. But such development should be in a manner which addresses environmental concerns and the question how water resources can best be allocated.

It has been debated whether hydroelectric generation is merely an in-stream water user or whether it also consumes water, in the sense of effectively taking away water from the river (Cooley et al., 2011). In the World Congress organized by the International Hydropower Association, 1417 June 2011 in Brazil, a special session was devoted to the question: does hydropower consume water? The session explored different interpretations of water "consumption" in an attempt to recognize the energy impacts on water (Aguilar et al., 2011). In this paper we provide scientific support for the argument that the production of hydroelectricity is in most cases a significant water consumer.

As an indicator of water consumption of hydroelectricity we use the concept of the water footprint, which measures the volume of freshwater consumed and polluted to produce the product along its supply chain. The water footprint of a 
product is equal to the sum of freshwater consumed or polluted divided by the quantity of production of the product (Hoekstra and Chapagain, 2008; Hoekstra et al., 2011). The water footprint consists of three components: the green water footprint (consumptive use of rainwater), the blue water footprint (consumptive use of ground or surface water) and the grey water footprint (the volume of water polluted). The analysis in this paper is restricted to the quantification of the blue water footprint of hydroelectricity and focuses on the consumptive use of water that relates to the evaporation from the artificial reservoirs that are created behind hydroelectric dams.

Storage of water behind large hydropower dams leads to consumptive water use through evaporation from the open water surface of the artificial lake. Gleick (1993) has shown that between 0.01 and $56 \mathrm{~m}^{3} \mathrm{GJ}^{-1}$, or on average $1.5 \mathrm{~m}^{3}$ of water per GJ of electricity produced is evaporated from hydroelectric facilities in California. In a recent study for New Zealand, Herath et al. (2011) estimated the water footprint of hydro-electric generation for eight plants and found values between 0.8 and $32 \mathrm{~m}^{3} \mathrm{GJ}^{-1}$. In another recent study, Pfister et al. (2011) report values between 0.3 and $170 \mathrm{~m}^{3} \mathrm{GJ}^{-1}$ based on a few cases from the USA, Switzerland and Tanzania. By combining the estimate of global evaporation from artificial water reservoirs in the world from Shiklomanov (2000) with data on global hydroelectric generation from Gleick (1993), Gerbens-Leenes et al. (2009a) estimated that the global average blue water footprint of electricity from hydropower is $22 \mathrm{~m}^{3} \mathrm{GJ}^{-1}$.

The objective of the current study is to estimate the blue water footprint of hydroelectricity for 35 selected reservoirs. First we estimate the evaporation throughout the year for the selected reservoirs. Next, we calculate the water footprint of hydropower based on the annual evaporation rate and energy generated. We have considered both the theoretical maximum and the actual hydroelectric generation of the plant. The theoretical maximum hydroelectric generation refers to the energy that could be generated with $100 \%$ hydropower availability. Since this theoretical maximum is not realistically attainable, comparisons among the hydropower plants and further discussion of the water footprint will be based on the actual energy generation.

The selection of the hydropower plants has been largely arbitrary and mostly based on the availability of data. The selected plants are shown in Fig. 1. All plants selected have been primarily built for the purpose of hydroelectric generation, although some serve other purposes as well. With the exception of the largest hydropower plants such as Itaipu, Tucurui, Sayano Shushenskaya, Robert-Bourossa, Yacyreta and Cahora Bassa all hydropower plants selected are the ones included in World Bank (1996). The 35 hydropower plants have a total capacity of about $73 \mathrm{GW}$ and represent $8 \%$ of the global installed hydroelectric capacity of $924 \mathrm{GW}$ in 2007 (IEA, 2010).

\section{Method and data}

The water footprint of electricity (WF, $\mathrm{m}^{3} \mathrm{GJ}^{-1}$ ) generated from hydropower is calculated by dividing the amount of water evaporated from the reservoir annually (WE, $\mathrm{m}^{3} \mathrm{yr}^{-1}$ ) by the amount of energy generated (EG, $\mathrm{GJ} \mathrm{yr}^{-1}$ ):

$\mathrm{WF}=\frac{\mathrm{WE}}{\mathrm{EG}}$

The total volume of evaporated water (WE, $\mathrm{m}^{3} \mathrm{yr}^{-1}$ ) from the hydropower reservoir over the year is:

$\mathrm{WE}=\left(10 \times \sum_{t=1}^{365} E\right) \times A$

where $E$ is the daily evaporation $\left(\mathrm{mm} \mathrm{day}^{-1}\right)$ and $A$ the area of the reservoir (ha)

Data on installed hydroelectric capacity, actual hydroelectric generation and reservoir area were obtained from the World Bank (1996). For some hydropower plants data were obtained from Goodland (1997) and other sources. Data on reservoir water holding capacity were obtained mainly from Chao et al. (2008).

There are a number of methods for the measurement or estimation of evaporation. These methods can be grouped into several categories including (Singh and Xu, 1997): (i) empirical, (ii) water budget, (iii) energy budget, (iv) mass transfer and ( $v$ ) a combination of the previous methods.

Empirical methods relate pan evaporation, actual lake evaporation or lysimeter measurements to meteorological factors using regression analyses. The weakness of these empirical methods is that they have a limited range of applicability. The water budget methods are simple and can potentially provide a more reliable estimate of evaporation, as long as each water budget component is accurately measured. However, owing to difficulties in measuring some of the variables such as the seepage rate in a water system the water budget methods rarely produce reliable results in practice (Lenters et al., 2005; Singh and Xu, 1997). In the energy budget method, the evaporation from a water body is estimated as the difference between energy inputs and outputs measured at a site. Energy budget methods are considered to be the most reliable in theory (Lenters et al., 2005; Singh and $\mathrm{Xu}, 1997)$, but require costly instrumentation and a large commitment of personnel for field work and data processing (Winter et al., 1995). The mass-transfer (aerodynamic) based methods utilize the concept of eddy motion transfer of water vapour from an evaporating surface to the atmosphere. The mass-transfer methods normally use easily measurable variables and give satisfactory results in many cases. However, measurement of wind speed and air temperature at inconsistent heights, have resulted in a large number of equations with similar or identical structure (Singh and Xu, 1997). The combination methods combine the mass transfer and energy 


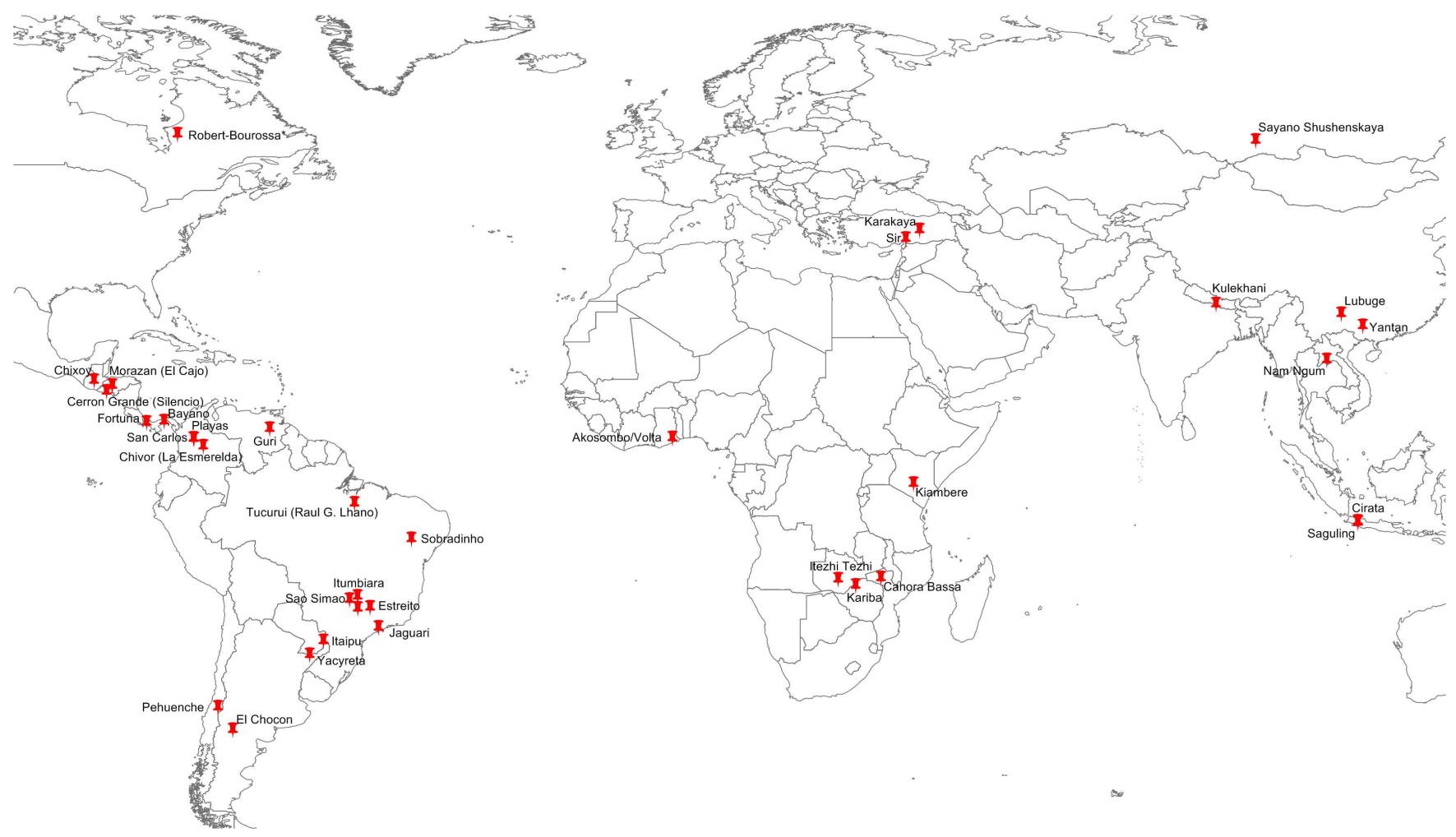

Fig. 1. Locations of the selected hydropower plants.

budget principles in a single equation. Two of the most commonly known combination methods are the Penman equation and the Penman-Monteith equation.

Owing to its limited empirical basis, the Penman-Monteith equation is more readily applicable to a variety of water bodies. In addition, the model takes into account heat storage within water bodies. Therefore, for the purpose of the current study the Penman-Monteith equation with heat storage is considered suitable for the estimation of evaporation from the selected hydropower reservoirs.

The evaporation from the water surface $\left(E, \mathrm{~mm} \mathrm{day}^{-1}\right)$ is estimated using the Penman-Monteith equation with an inclusion of water body heat storage. This equation is written as (McJannet et al., 2008):

$$
E=\frac{1}{\lambda} \times\left(\frac{\Delta_{\mathrm{w}} \times\left(R_{\mathrm{n}}-G\right)+\gamma \times f(u) \times\left(e_{\mathrm{w}}-e_{\mathrm{a}}\right)}{\Delta_{\mathrm{w}}+\gamma}\right)
$$

where $E$ is open water evaporation $\left(\mathrm{mm} \mathrm{day}^{-1}\right) ; \lambda$ the latent heat of vaporization $\left(\mathrm{MJ} \mathrm{kg}^{-1}\right) ; \Delta_{\mathrm{W}}$ the slope of the temperature saturation water vapour curve at water temperature $\left(\mathrm{kPa}^{\circ} \mathrm{C}^{-1}\right) ; R_{\mathrm{n}}$ net radiation $\left(\mathrm{MJ} \mathrm{m}^{-2} \mathrm{day}^{-1}\right) ; G$ the change in heat storage in the water body $\left(\mathrm{MJ} \mathrm{m}^{-2} \mathrm{day}^{-1}\right) ; f(u)$ the wind function $\left(\mathrm{MJ} \mathrm{m}^{-2} \mathrm{day}^{-1} \mathrm{kPa}^{-1}\right) ; e_{\mathrm{w}}$ the saturated vapour pressure at water temperature $(\mathrm{kPa}) ; e_{\mathrm{a}}$ the vapour pressure at air temperature $(\mathrm{kPa})$; and $\gamma$ the psychrometric constant $\left(\mathrm{kPa}^{\circ} \mathrm{C}^{-1}\right)$. The full description of the method used is presented in the Supplement.
Daily values of mean air temperature, dew point temperature and wind speed for the selected meteorological stations were obtained from NCDC (2009). The daily data for the years 1996-2005 were averaged in order to fill missing values and smooth out some inconsistencies in the data. Monthly values of cloud cover and percentage of maximum possible sunshine with a spatial resolution of 10 arc minute were obtained from the CRU CL-2.0 database (New et al., 2002). The cloud cover and sunshine duration were available only as monthly averages for the period 1961-1990. Therefore the monthly average values were used as daily values for each month of the year.

The water footprint of electricity from hydropower is compared with the water footprint of electricity from combustion of primary crops. The latter has been calculated per type of crop by first multiplying the water footprint of the primary crop in $\mathrm{m}^{3}$ ton $^{-1}$ from Mekonnen and Hoekstra (2011) by the harvest index for that crop to get the water footprint in $\mathrm{m}^{3}$ per ton of total biomass harvested. Harvest indices were taken from Gerbens-Leenes et al. (2009a, b). Next, the water footprint of total biomass was divided by the bio-electricity output per unit of crop (GJ ton $\left.{ }^{-1}\right)$ as reported by GerbensLeenes et al. (2008). 


\section{Results: the water footprint of hydroelectricity}

The aggregated blue water footprint of the 35 selected hydropower plants is $90 \mathrm{Gm}^{3} \mathrm{yr}^{-1}$, which is equivalent to $10 \%$ of the blue water footprint of global crop production in the year 2000 (Mekonnen and Hoekstra, 2011; Fader et al., 2011). The total blue water footprint of hydroelectric generation in the world must be considerably larger if one considers the fact that this study covers only $8 \%$ of the global installed hydroelectric capacity. The annual evaporation from hydropower reservoirs depends on both climate (which determines the evaporation from the water surface in $\mathrm{mm} \mathrm{yr}^{-1}$ ) and reservoir area.

The water footprint of electricity from hydropower for the 35 selected hydropower plants is presented in Table 1 . The average water footprint of electricity from hydropower for the selected plants is $68 \mathrm{~m}^{3} \mathrm{GJ}^{-1}$. There is a large variation in water footprint among the different power plants, ranging from $0.3 \mathrm{~m}^{3} \mathrm{GJ}^{-1}$ for San Carlos in Colombia to $846 \mathrm{~m}^{3} \mathrm{GJ}^{-1}$ for Akosombo-Kpong in Ghana.

Most of the reservoirs show an evaporation rate between 2000 and $3000 \mathrm{~mm} \mathrm{yr}^{-1}$. Reservoirs in the (sub)tropics have generally a higher evaporation rate than reservoirs in temperate regions. The surface water evaporation varies from no more than $486 \mathrm{~mm} \mathrm{yr}^{-1}$ from the Sayano Shushenskaya reservoir in Russia to $3059 \mathrm{~mm} \mathrm{yr}^{-1}$ from the Cahora Bassa reservoir in the Zambezi River in Mozambique (Table 1). Minimum and maximum evaporation rates thus differ by a factor of six, which partially explains the differences between the water footprints of different hydropower reservoirs. The size of the reservoir surface in relation to the installed hydroelectric capacity, however, has a much bigger impact on the ultimate water footprint of hydroelectricity. While the average reservoir area per unit of installed capacity in the reservoirs studied is $83 \mathrm{ha} \mathrm{MW}^{-1}$, the minimum is $0.26 \mathrm{ha} \mathrm{MW}^{-1}$ (San Carlos reservoir, Colombia) and the maximum 720 ha MW $^{-1}$ (Akosombo-Kpong in the Volta River, Ghana). The total evaporation from a hydropower reservoir thus depends more on its size than on climate. This is illustrated in Fig. 2, which shows a more or less linear relationship between the water footprint of the power plants and ha $\mathrm{MW}^{-1}$. Hydropower plants that inundate a large area per unit of installed capacity have in general a larger water footprint per unit of electricity generated than those that flood a small area per unit of installed capacity.

The largest hydropower plant in terms of installed hydroelectric capacity in this study, the Itaipu dam in the Paraná River at the border of Brazil and Paraguay, has a water footprint of $7.6 \mathrm{~m}^{3} \mathrm{GJ}^{-1}$. The second-largest studied hydropower plant in terms of MW, the Guri reservoir in Brazil, has a water footprint that is close to the global average of $68 \mathrm{~m}^{3} \mathrm{GJ}^{-1}$ found in this study. The largest plant in terms of MW that has a water footprint far beyond the average found in this study is the Cahora Bassa dam in the Zambezi River in Mozambique, with a water footprint of $186 \mathrm{~m}^{3} \mathrm{GJ}^{-1}$.

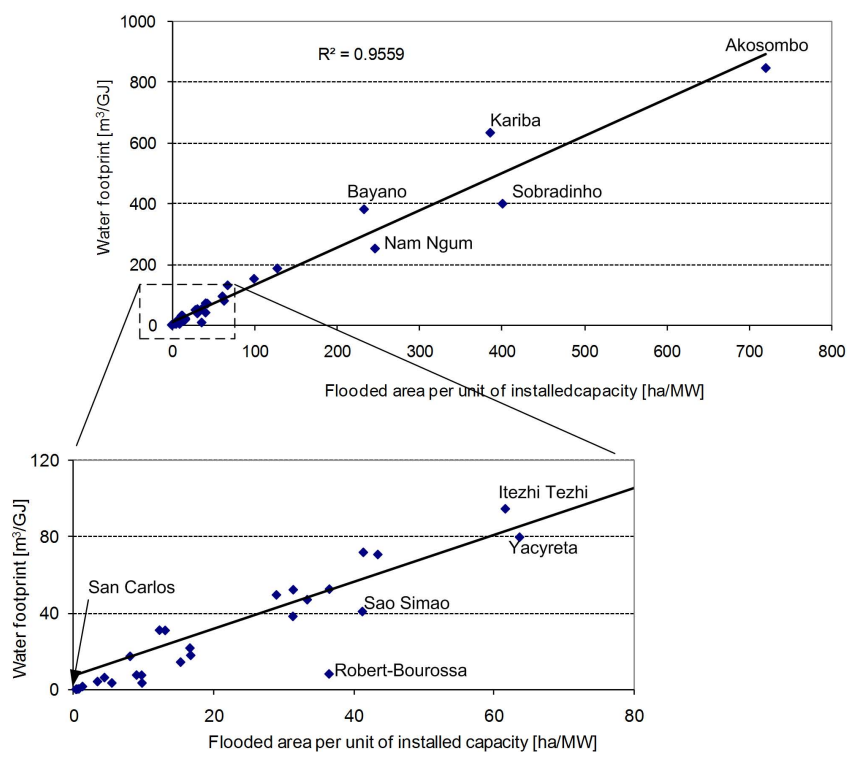

Fig. 2. Relation between the water footprint of hydroelectricity and the flooded area per unit of installed hydroelectric capacity.

\section{Comparison with the water footprints of other forms of energy}

When we compare the water footprint of electricity from hydropower with the water footprint of electricity from other renewable sources, it appears that hydroelectricity has a relatively large water footprint per GJ. The blue water footprint of electricity from wind and solar energy is estimated to be well below $1 \mathrm{~m}^{3} \mathrm{GJ}^{-1}$ (Gerbens-Leenes et al., 2009a). The blue water footprint of bio-electricity - when derived from combustion of the full biomass of primary crops ranges from zero to $40 \mathrm{~m}^{3} \mathrm{GJ}^{-1}$, depending on which crop is used for comparison and to which extent it is irrigated. The $40 \mathrm{~m}^{3} \mathrm{GJ}^{-1}$ refers to bio-electricity from combustion of cotton, which is a rather theoretical example, because cotton is in practice not used for the purpose of electricity generation. Also other crops are rarely used for that purpose. More common feedstock for the generation of bio-electricity are crop residues, animal manure, wood wastes from forestry and industry, residues from food and paper industries, municipal green wastes and sewage sludge. In all those cases, the water footprint of bio-electricity will be much lower than the water footprint of bio-electricity from combustion of primary crops, because the water footprint of biomass is largely attributed to the primary product and not to the residues and waste (Hoekstra et al., 2011). Figure 3 compares the blue water footprint of electricity from hydropower with the total (green + blue + grey) water footprint of electricity from combustion of primary crops. For a fair comparison one should compare the blue water footprints. But even when comparing the total water footprints, bioelectricity from a number of crops - including sugar beet, sugar cane and maize - will 
Table 1. Water footprint of electricity for selected hydropower plants.

\begin{tabular}{|c|c|c|c|c|c|c|c|}
\hline \multirow{2}{*}{$\begin{array}{l}\text { Power } \\
\text { plant }\end{array}$} & \multirow[t]{2}{*}{ Country } & \multirow{2}{*}{$\begin{array}{r}\text { Reservoir } \\
\text { area (ha) }\end{array}$} & \multirow{2}{*}{$\begin{array}{r}\text { Installed } \\
\text { capacity (MW) }\end{array}$} & \multicolumn{2}{|c|}{ Evaporation } & \multicolumn{2}{|c|}{$\begin{array}{l}\text { Water footprint } \\
\qquad\left(\mathrm{m}^{3} \mathrm{GJ}^{-1}\right)\end{array}$} \\
\hline & & & & $\left(\mathrm{mm} \mathrm{yr}^{-1}\right)$ & $\left(\mathrm{Gm}^{3} \mathrm{yr}^{-1}\right)$ & $\begin{array}{r}\text { for theoretical } \\
\text { maximum } \\
\text { energy production }\end{array}$ & $\begin{array}{r}\text { for actual } \\
\text { energy } \\
\text { production }\end{array}$ \\
\hline Akosombo-Kpong* & Ghana & 850200 & 1180 & 2185 & 18.58 & 499 & 846 \\
\hline Bayano & Panama & 35000 & 150 & 2156 & 0.75 & 160 & 381 \\
\hline Cahora Bassa & Mozambique & 266000 & 2075 & 3059 & 8.14 & 124 & 186 \\
\hline Cerron Grande (Silencio) & El Salvador & 13500 & 135 & 2267 & 0.31 & 71.9 & 152 \\
\hline Chivor (La Esmerelda) & Colombia & 1200 & 1008 & 1607 & 0.02 & 0.6 & 1.7 \\
\hline Chixoy & Guatemala & 1300 & 300 & 2393 & 0.03 & 3.3 & 6.4 \\
\hline Cirata & Indonesia & 6100 & 500 & 2626 & 0.16 & 10.2 & 31.1 \\
\hline El Chocon & Argentina & 81600 & 1200 & 2089 & 1.70 & 45.0 & 131 \\
\hline Estreito & Brazil & 45600 & 1050 & 2285 & 1.04 & 31.5 & 70.6 \\
\hline Fortuna & Panama & 1000 & 300 & 2251 & 0.02 & 2.4 & 4.3 \\
\hline Guri & Venezuela & 426000 & 10300 & 2787 & 11.87 & 36.6 & 71.7 \\
\hline Itaipu & Brazil-Paraguay & 135000 & 14000 & 1808 & 2.44 & 5.5 & 7.6 \\
\hline Itezhi Tezhi & Zambia & 37000 & 600 & 2572 & 0.95 & 50.3 & 94.4 \\
\hline Itumbiara & Brazil & 76000 & 2082 & 2239 & 1.70 & 26 & 52.5 \\
\hline Jaguari & Brazil & 7001 & 460 & 1782 & 0.12 & 8.6 & 14.4 \\
\hline Karakaya & Turkey & 29800 & 1800 & 1920 & 0.57 & 10.1 & 21.8 \\
\hline Kariba & Zambia-Zimbabwe & 510000 & 1320 & 2860 & 14.59 & 350 & 633 \\
\hline Kiambere & Kenya & 2500 & 150 & 2356 & 0.06 & 12.5 & 18.0 \\
\hline Kulekhani & Nepal & 2000 & 60 & 1574 & 0.03 & 16.6 & 47.0 \\
\hline Lubuge & China & 400 & 600 & 1040 & 0.00 & 0.2 & 0.5 \\
\hline Marimbondo & Brazil & 43800 & 1400 & 2330 & 1.02 & 23.1 & 38.3 \\
\hline Morazan (El Cajo) & Honduras & 9400 & 300 & 2622 & 0.25 & 26.1 & 52.2 \\
\hline Nam Ngum & Laos & 37000 & 150 & 2411 & 0.89 & 189 & 252 \\
\hline Pehuenche & Chile & 200 & 500 & 1884 & 0.00 & 0.2 & 0.4 \\
\hline Playas & Colombia & 1100 & 204 & 1663 & 0.02 & 2.8 & 3.6 \\
\hline Robert-Bourossa-La Grande-2A** & Canada & 281500 & 7722 & 586 & 1.65 & 6.8 & 8.3 \\
\hline Saguling & Indonesia & 5600 & 700 & 2422 & 0.14 & 6.1 & 17.5 \\
\hline San Carlos & Colombia & 300 & 1145 & 1726 & 0.01 & 0.1 & 0.3 \\
\hline Sao Simao & Brazil & 67400 & 1635 & 2229 & 1.50 & 29.1 & 40.8 \\
\hline Sayano Shushenskaya & Russia & 62100 & 6400 & 486 & 0.30 & 1.5 & 3.6 \\
\hline Sir & Turkey & 4100 & 315 & 1973 & 0.08 & 8.1 & 31.0 \\
\hline Sobradinho & Brazil & 421400 & 1050 & 2841 & 11.97 & 362 & 399 \\
\hline Tucurui (Raul G. Lhano) & Brazil & 243000 & 8400 & 2378 & 5.78 & 21.8 & 49.5 \\
\hline Yacyreta & Argentina/Paraguay & 172000 & 2700 & 1907 & 3.28 & 47.8 & 79.6 \\
\hline Yantan & China & 10800 & 1210 & 1646 & 0.18 & 4.7 & 7.7 \\
\hline Total & & 3886901 & 73101 & & 90 & & \\
\hline Average & & & & 2320 & & 39 & 68 \\
\hline
\end{tabular}

* The data are for the combined Akosombo-Kpong system. Kpong is a runoff power plant using Akosombo dam. Akosombo and Kpong generate 1020 MW and 160 MW, respectively. ** Robert-Bourossa together with La Grande-2A use the Robert-Bourossa reservoir and generate $5616 \mathrm{MW}$ and $2106 \mathrm{MW}$ respectively. Energy generation of La Grand-2-A is assumed to be half of that of Robert-Bourossa.

have a smaller water footprint than hydroelectricity. In other words, one drop of blue water allocated for consumption for hydroelectric generation generally yields much less energy than one drop of blue water allocated for consumption in crop production for generating feedstock for bioelectricity. This is not to suggest that in general it is advisable to allocate water to grow crops for producing bioelectricity rather than to generate a much lower amount of hydroelectricity at the cost of the same volume of water. In many cases this alternative allocation is not a reasonable choice, or even impossible (e.g. due to the unavailability of suitable land). Besides, for such broad decisions as investing in different sectors, one needs to take into account all relevant economic, social and environmental factors, not the factor of water productivity alone. Also one should account for the fact that many hydroelectric dams are designed to serve other purposes as well. What we do want to argue, however, is that hydroelectric generation is generally a large water consumer and that in allocating water to hydroelectric generation it is advisable to explore the foregone costs by not allocating the water to alternative uses, either upstream or downstream of the location of a planned hydropower reservoir. Alternative uses include crop growing for bioelectricity, but more common alternatives are to allocate the blue water to grow crops for food, feed, fibers or 


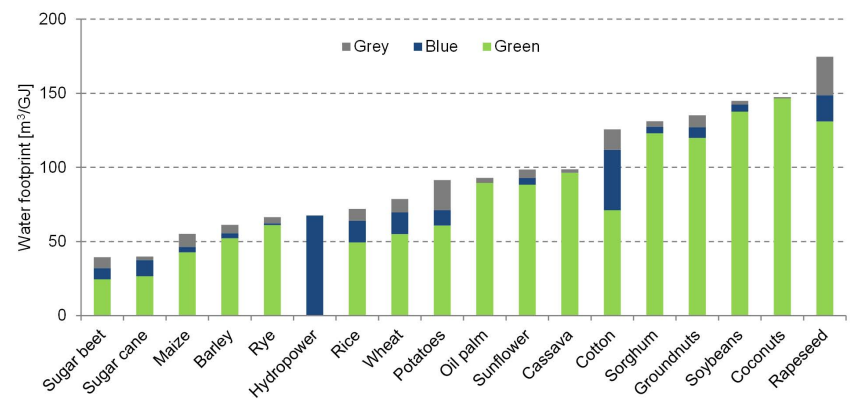

Fig. 3. Global average water footprint of electricity from hydropower compared to the water footprint of electricity from combustion of primary crops.

biofuel or to let the blue water in the river to maintain environmental flows.

\section{Sensitivity analysis}

The sensitivity of the calculated lake evaporation to errors in input data was tested by varying the following parameters: air temperature, wind speed, water depth and lake area. On average, for the lakes studied, a variation of the water depth by $\pm 50 \%$ has little effects on the evaporation $( \pm 1.6 \%)$. Variation in wind speed has even lower effects on the annual lake evaporation. This is in agreement with the finding of $\mathrm{Xu}$ and Singh (1998). Therefore, possible data errors in these two parameters have very little effect on our final result. However, the effects of changes in air temperature and lake area are quite significant. On average, for the lakes studied, variation of the air temperature by $\pm 10 \%$ results in an increase or decrease of the evaporation by almost an equal percentage. The total evaporation amount per year is equal to the product of the evaporation rate $(\mathrm{mm})$ and surface area. Thus, an error in the surface area of the lake by $10 \%$ leads to an error in total evaporation of $10 \%$ as well.

Besides, there could be errors associated with the use of the climatic data measured over the land surface instead of over the water surface. Although the model applied is shown to estimate the water temperature reasonably well when verified against measured data (Keijman, 1974; De Bruin, 1982; Finch, 2001), we may not fully capture the actual water temperature, particularly at a daily time step, as there will be some time lag between the equilibrium temperature (the temperature at which the net rate of heat exchange equals zero) and the water temperature. This may lead to some error in the annual evaporation estimate.

\section{Discussion}

The water footprints of the artificial reservoirs analyzed in this study were fully attributed to hydroelectric generation, even though some of the reservoirs serve other purposes as well, such as flood control and irrigation. We justify this choice by the fact that all selected hydropower dams and associated reservoirs were primarily created for hydroelectric generation. Future research could be directed towards the analysis of the water footprint of reservoirs created for storing water for irrigation or other purposes and on tackling the water footprint attribution issue when reservoirs are used for multiple purposes.

The model output is sensitive to a number of input parameters such as air temperature, wind speed and water body depth as shown in the previous section. Since climatic data at the dam site are available only for a few plants, data from the most nearby climatic stations have been used, some of which are a bit far from the reservoir. Due to the uncertainties in the input data, the data presented should be seen as indicative. The order of magnitude of the results, however, will not change with better data, so that the results are good enough to compare the water footprint of hydroelectricity with the water footprint of other forms of electricity and to make rough comparisons between the water footprints of different hydropower sites.

Most reservoirs have a varying water surface area over time, as a result of changes in water volume during the year and between years. The difference between minimum and maximum area relative to the maximum area over a multiyear period differs greatly across reservoirs. In this study we have used a fixed reservoir area as provided by World Bank (1996) and Goodland (1997). Since reported areas generally refer to the maximum, this can lead to some overestimation of evaporation over the year. It is very difficult to find good data of area changes over the year; future studies devoted to particular sites could improve this.

We have estimated the water footprint per reservoir by considering the total evaporation from the reservoir, whereas one could argue that before the reservoir was created there was evaporation from the area as well, probably not so much from the original flowing river (since in most cases the reservoir area is much larger than the original river water area) but possibly significant from the inundated land. However, here it is relevant to recall the definition and meaning of the water footprint. The water footprint is not meant to refer to additional evaporation (compared to some reference situation), but for quantifying the volume of water consumption that can be associated with a specific human purpose (Hoekstra et al., 2011). From this perspective, the full reservoir evaporation can be attributed to the purpose of the reservoir.

The consumptive water use of a reservoir has been quantified by considering total evaporation, even though one could hypothesize that a fraction of the evaporated water will return to the reservoir or the catchment of the reservoir. In this study, it has been assumed that evaporated water from a reservoir will not return to the reservoir or even the catchment in a significant way. Although land-use changes such as building a reservoir can influence climate at a regional or continental scale through influencing moisture recycling (Van der Ent, 
2010; Eltahir et al., 1996), this process is relevant on a larger scale than the catchment, so that most of the water evaporated from a catchment can generally be considered "lost" for reuse in the same catchment.

The study has been limited to the estimation of the evaporation from reservoirs, i.e. the so-called operational water footprint of hydroelectric generation. The study does not include an assessment of the supply-chain water footprint of hydroelectric generation, which is expected to be much smaller than the operational water footprint (Inhaber, 2004; Fthenakis and Kim, 2010). The supply-chain water footprint refers to the water footprint of producing the materials used in the construction and the operation and maintenance of the site.

The water footprint is a resource use indicator, not an ecological or social impact indicator. Dams are often associated with all sorts of ecological impacts (river fragmentation, effects on water quality and biodiversity) and social impacts (displacement of people). It is to be appreciated that the water footprint of hydroelectric generation refers to freshwater consumption related to hydroelectric generation; the water footprint is not an all-inclusive indicator that reflects all environmental and social impacts of a dam and needs to be complemented with other relevant resource use and impact indicators in order to provide a full understanding of all relevant issues.

Some authors have suggested to redefine the water footprint from a volumetric measure to a local environmental impact index, by multiplying volumes by impact factors, whereby impact factors are defined based on local water scarcity. In this way, one would obtain weighted volumes of water consumption (Pfister and Hellweg, 2009; Berger and Finkbeiner, 2010). However, highly relevant information is lost in this way, because knowing the volumes of water consumed for hydroelectric generation is important in the discussion about water resources allocation. Besides, it is doubtful whether weighting volumes based on water scarcity to obtain one simple impact index can do justice to the variety of local factors that determine the various sorts of environmental and social impacts that can occur as a result of water consumption from a reservoir or as a result of a dam in a broader sense. Therefore, we recommend to consider environmental and social impacts of a dam separately and in addition to the water footprint of a reservoir, acknowledging that the latter reflects water consumption only. The main consideration from Pfister and Hellweg (2009) and Berger and Finkbeiner (2010) behind the proposal to define the water footprint as an impact indicator rather than as a resource use indicator is that this would be in line with how the carbon footprint is defined. In the research field of Life Cycle Assessment, carbon footprint is indeed interpreted as an impact indicator, but wrongly so, as argued before (Hoekstra et al., 2011). The carbon footprint is a measure of the amount of greenhouse gases emitted to the environment from human activities and does not describe environmental impacts associated with the emission of these greenhouse gases. The water footprint is consistent with the ecological and carbon footprint; they all show pressures on natural resources or on the earth's assimilation capacity, not impacts (Hoekstra et al., 2009, 2011; Hoekstra, 2009).

\section{Conclusions}

Hydroelectric generation has historically been considered as a non-consumptive water user; however, through the estimation of the blue water footprint of hydroelectricity at 35 sites, this study finds that hydropower is a large consumptive user of water. The amount of water lost through evaporation annually from the selected reservoirs is equivalent to $10 \%$ of the global blue water footprint related to crop production. The 35 sites represent only $8 \%$ of the global installed hydroelectric capacity. The study shows that the range of water footprint values for the different hydropower plants is very wide. Although local climate has an influence, the water footprint of hydroelectricity is largely influenced by the area flooded per unit of installed capacity. The water footprint linearly increases with the area flooded per unit of installed capacity.

The water evaporated from the reservoir is seldom taken into account in assessing the pros and cons of constructing dams for hydroelectric generation. This study demonstrates that accounting for water loss through evaporation is an additional consideration when evaluating the environmental, social and economic sustainability of a proposed dam or in the evaluation of hydropower as an energy source. We recommend that water footprint assessment is added as a component in evaluations of newly proposed hydropower plants as well as in the evaluation of existing hydroelectric dams, so that the consequences of the water footprint of hydroelectric generation on downstream environmental flows and other water users can be evaluated.

The water footprint of hydroelectric dams should be considered in the context of the river basin in which this water footprint occurs, because competition over water and possible alternative uses of water differ per basin. This study contributes new information that can be used in river basin planning and water allocation decisions.

Sustainable development of hydropower requires the accounting and internalization of all external costs including water consumption. Internalization means that the economic and environmental costs of the water consumed are charged to the operator of a hydropower plant and included in the price of hydroelectricity. It should thereby be acknowledged that water consumption costs vary within the year and across river basins, since the degree of water scarcity and competition over water depend on the period within the year and local circumstances.

The current study does not claim to be exhaustive in terms of showing both the beneficial and negative effects of hydropower. The study has been restricted to the estimation of the water footprint of different hydropower plants. 
Environmental issues surrounding hydropower dams relate to, for example: physical, chemical, biological and geomorphological aspects of blocking a river; flooding of natural habitats and related loss of plants and animals; alteration of water flow regimes; and water quality problems due to the decay of submerged vegetation. On the other hand, hydropower is often perceived as a clean and cost-effective source of renewable energy. Many countries rely upon hydropower for a substantial portion of their electricity supply. Between 1973 and 2008, hydroelectric generation grew from $1295 \mathrm{TWh}$ to $3288 \mathrm{TWh}$, which is a growth by a factor 2.5 (IEA, 2010). Further development of hydropower should take into account all the associated environmental and social costs. In this respect, the water footprint of hydroelectricity, i.e. the consumptive use of water, should be considered as one item in environmental impact assessment studies for newly proposed hydroelectric dams.

\section{Supplementary material related to this article is available online at: http://www.hydrol-earth-syst-sci.net/16/179/2012/ hess-16-179-2012-supplement.pdf.}

Edited by: S. Thompson

\section{References}

Aguilar, S., Louw, K., and Neville, K.: IHA World Congress Bulletin, International Institute for Sustainable Development (IISD) and International Hydropower Association (IHA), Issue 1, Vol. 139, No. 5, available at: www.iisd.ca/ymb/hydro/iha2011, 2011.

Berger, M. and Finkbeiner M.: Water footprinting: How to address water use in Life Cycle Assessment?, Sustainability, 2, 919-944, 2010.

Chao, B. F., Wu, Y. H., and Li, Y. S.: Impact of artificial reservoir water impoundment on global sea level, Science, 320, 212-214, 2008.

Cooley, H., Fulton, J., and Gleick, P.: Water for energy: Future water needs for electricity in the Intermountain West, Pacific Institute, Oakland, USA, 2011.

De Bruin, H. A. R.: Temperature and energy balance of a water reservoir determined from standard weather data of a land station, J. Hydrol., 59, 261-274, 1982.

Eltahir, E. A. B. and Bras, R. L.: Precipitation recycling, Rev. Geophys., 34, 367-378, 1996.

Fader, M., Gerten, D., Thammer, M., Heinke, J., Lotze-Campen, H., Lucht, W., and Cramer, W.: Internal and external green-blue agricultural water footprints of nations, and related water and land savings through trade, Hydrol. Earth Syst. Sci., 15, 1641-1660, doi:10.5194/hess-15-1641-2011, 2011.

Finch, J. W.: A comparison between measured and modelled open water evaporation from a reservoir in south-east England, Hydrol. Process., 15, 2771-2778, 2001.

Fthenakis, V. and Kim, H. C.: Life-cycle uses of water in U.S. electricity generation, Renew. Sust. Energ. Rev., 14, 2039-2048, 2010.
Gerbens-Leenes, P. W., Hoekstra, A. Y., and Van der Meer, Th. H.: Water footprint of bio-energy and other primary energy carriers, Value of Water Research Report Series No. 29, UNESCO-IHE, Delft, the Netherlands, 2008.

Gerbens-Leenes, P. W., Hoekstra, A. Y., and Van der Meer, T. H.: The water footprint of energy from biomass: A quantitative assessment and consequences of an increasing share of bio-energy in energy supply, Ecol. Econ., 68, 1052-1060, 2009a.

Gerbens-Leenes, W., Hoekstra, A. Y., and Van der Meer, T. H.: The water footprint of bioenergy, Proc. Natl. Acad. Sci. USA, 106, 10219-10223, 2009b.

Gleick, P. H. (Ed.): Water in crisis, A guide to the world's freshwater resources, Oxford University Press, New York, 1993.

Goodland, R.: Environmental sustainability in the hydro industry, in Workshop Proceedings of IUCN-The World Conservation Union and The World Bank Group, Gland, Switzerland, 69-102, 1997.

Herath, I., Deurer, M., Horne, D., Singh, R., and Clothier, B.: The water footprint of hydroelectricity: a methodological comparison from a case study in New Zealand, J. Clean. Prod., 19, 15821589, 2011.

Hoekstra, A. Y.: Human appropriation of natural capital: A comparison of ecological footprint and water footprint analysis, Ecol. Econ., 68, 1963-1974, 2009.

Hoekstra, A. Y. and Chapagain, A. K.: Globalization of water: Sharing the planet's freshwater resources, Blackwell Publishing, Oxford, UK, 2008.

Hoekstra, A. Y., Gerbens-Leenes, W., and Van der Meer, T. H.: Water footprint accounting, impact assessment, and lifecycle assessment, Proc. Natl. Acad. Sci. USA, 106, E114, doi:10.1073/pnas.0909948106, 2009.

Hoekstra, A. Y., Chapagain, A. K., Aldaya, M. M., and Mekonnen, M. M.: The water footprint assessment manual: Setting the global standard, Earthscan, London, UK, 2011.

IEA: Key world energy statistics 2010, International Energy Agency, Paris, France, 18-19, 2010.

Inhaber, H.: Water use in renewable and conventional electricity production, Energ. Source, 26, 309-322, 2004.

Keijman, J. Q.: The estimation of the energy balance of a lake from simple weather data, Bound.-Lay. Meteorol., 7, 399-407, 1974.

Lenters, J. D., Kratz, T. K., and Bowser, C. J.: Effects of climate variability on lake evaporation: Results from a long-term energy budget study of sparkling lake, Northern Wisconsin, USA, J. Hydrol., 308, 168-195, 2005.

Lerer, L. B. and Scudder, T.: Health impacts of large dams, Environ. Impact Asses., 19, 113-123, 1999.

McJannet, D. L., Webster, I. T., Stenson, M. P., and Sherman, B. S.: Estimating open water evaporation for the Murray Darling basin, Report for CSIRO, Australia, 2008.

Mekonnen, M. M. and Hoekstra, A. Y.: The green, blue and grey water footprint of crops and derived crop products, Hydrol. Earth Syst. Sci., 15, 1577-1600, doi:10.5194/hess-15-15772011, 2011.

NCDC, Global surface summary of the day, National Climatic Data Centre, available at: http://www.ncdc.noaa.gov/cgi-bin/res40.pl? page $=$ gsod.html, last access: 5 February 2009.

New, M., Lister, D., Hulme, M., and Makin, I.: A high-resolution data set of surface climate over global land areas, Climate Res. 21, 1-25, 2002.

Pfister, S. and Hellweg, S.: The water "shoesize" vs. footprint of 
bioenergy, Proc. Natl. Acad. Sci. USA, 106, E93-E94, 2009.

Pfister, S., Saner, D., and Koehler, A.: The environmental relevance of water consumption in global power production, Int. J. Life Cycle Assess., 16, 580-591, 2011.

Poff, N. L., Richter, B. D., Arthington, A. H., Bunn, S. E., Naiman, R. J., Kendy, E., Acreman, M., Apse, C., Bledsoe, B. P., Freeman, M. C., Henriksen, J., Jacobson, R. B., Kennen, J. G., Merritt, D. M., O'Keeffe, J. H., Olden, J. D., Rogers, K., Tharme, R. E. and Warner, A.: The natural flow regime: a paradigm for river conservation and restoration, Bioscience, 47, 769-784, 1997.

Rosenberg, D. M., Bodaly, R. A., and Usher, P. J.: Environmental and social impacts of large scale hydroelectric development: who is listening?, Glob. Environ. Change, 5, 127-148, 1995.

Scudder, T.: Social impacts of large dams, in Workshop Proceedings of IUCN-The World Conservation Union and The World Bank Group, Gland, Switzerland, 41-68, 1997.

Shiklomanov, I. A.: Appraisal and assessment of world water resources, Water Int., 25, 11-32, 2000.

Singh, V. P. and Xu, C.-Y.: Evaluation and generalization of 13 mass-transfer equations for determining free water evaporation, Hydrol. Process., 11, 311-323, 1997.

Sternberg, R.: Hydropower: dimensions of social and environmental coexistence, Renew. Sust. Energ. Rev., 12, 1588-1621, 2008.
Sternberg, R.: Hydropower's future, the environment, and global electricity systems, Renew. Sust. Energ. Rev., 14, 713-723, 2010.

Tilt, B., Braun, Y., and He, D.: Social impacts of large dam projects: A comparison of international case studies and implications for best practice, J. Environ. Manage., 90 (Supplement 3), S249S257, 2009.

Van der Ent, R. J., Savenije, H. H. G., Schaefli, B., and Steele-Dunne, S. C.: Origin and fate of atmospheric moisture over continents, Water Resour. Res., 46, W09525, doi:10.1029/2010WR009127, 2010.

Winter, T. C., Rosenberry, D. O., and Sturrock, A. M.: Evaluation of 11 equations for determining evaporation for a small lake in the north central united states, Water Resour. Res., 31, 983-993, 1995.

World Bank: The World Bank's experience with large dams: a preliminary review of impacts, Operations Evaluation Department, World Bank, Washington, DC, US, 1996.

World Commission on Dams: Dams and development: a new framework for decision-making, Earthscan, London, UK, 2000.

$\mathrm{Xu}, \mathrm{C}$.-Y. and Singh, V. P.: Dependence of evaporation on meteorological variables at different time-scales and intercomparison of estimation methods, Hydrol. Process., 12, 429-442, 1998. 